\title{
On-line micro column preconcentration system based on amino bimodal mesoporous silica nanoparticles as a novel adsorbent for removal and speciation of chromium (III, VI) in environmental samples
}

\author{
Hamid Shirkhanloo ${ }^{1,2^{*}}$, Aisan Khaligh ${ }^{3}$, Farideh Golbabaei ${ }^{4}$, Zargham Sadeghi ${ }^{1 *}$, Amir Vahid ${ }^{2}$ and Alimorad Rashidi ${ }^{2}$
}

\begin{abstract}
Background: Chromium (VI) has toxic and carcinogenic effects. So, determination and speciation of chromium in environmental samples is very important in view of health hazards. In this study, solid phase extraction (SPE) based on bulky amine-functionalized bimodal mesoporous silica nanoparticles ( $\left.\mathrm{NH}_{2}-\mathrm{UVM}-7\right)$ as a novel nanoadsorbent was applied for preconcentration and speciation of chromium (III, VI) in water samples.
\end{abstract}

Methods: UVM-7 was synthesized via atrane route and subsequently functionalized with amino silane via grafting method. In SPE procedure, polymer tubing as a micro-column was filled with $\mathrm{NH}_{2}-\mathrm{UVM}-7$ adsorbent. Preconcentration and speciation of $\mathrm{Cr}$ (III) and $\mathrm{Cr}(\mathrm{VI})$ ions with $\mathrm{NH}_{2}-\mathrm{UVM}-7$ were obtained in water samples due to the fact that only $\mathrm{Cr}(\mathrm{VI})$ ions can be complexed with- $\mathrm{NH}_{2}$ groups at optimized $\mathrm{pH}$. Finally, chromium concentration was determined by flame atomic absorption spectrometry (F-AAS).

Results: TEM, XRD, and SEM results confirmed the beneficial properties of $\mathrm{NH}_{2}-\mathrm{UVM}-7$ as the adsorbent for chromium extraction. Under the optimal conditions, linear calibration curve, detection limit and preconcentration factor were obtained 6-320 $\mu \mathrm{g} / \mathrm{L}, 1.2 \mu \mathrm{g} / \mathrm{L}$ and 66.7, respectively (RSD $<5 \%$ ). The efficiency of nanoadsorbent for preconcentration and extraction of $\mathrm{Cr}(\mathrm{VI})$ was $96 \%$, whereas it was less than $5 \%$ for $\mathrm{Cr}$ (III).

Conclusions: The developed $\mathrm{NH}_{2}$-UVM7-based SPE/F-AAS method has enough sensitively and simplicity for speciation and determination of $\mathrm{Cr}(\mathrm{VI})$ and $\mathrm{Cr}$ (III) ions in real water samples. Good recoveries, with low detection limits and good preconcentration factors are the main advantages of this procedure.

Keywords: Chromium, Speciation, Removal, Solid phase extraction, Amine-functionalized UVM-7, Flame atomic absorption spectrometry

\section{Background}

Heavy metals in industrial and municipal effluent water (IMEW) are important sources of water contamination. The contamination and quality of IMEW are its main concern especially in the regions with limited water resources The refinery effluents are one of the most

\footnotetext{
* Correspondence: hamidshirkhanloo@yahoo.ca; research@piho.org ${ }^{1}$ Occupational and Environmental Health Research Center (OEHRC), Iranian Petroleum Industry Health Research Institute (IPIHRI-PIHO), Tehran 1485733111, Iran ${ }^{2}$ Research Institute of Petroleum Industry (RIPI), Tehran 14665-1137, Iran Full list of author information is available at the end of the article
}

important water pollution sources which can release a large quantity of heavy metals by crude oil-processing and petrochemical industries. In such region, heavy metals such as $\mathrm{Ni}, \mathrm{V}, \mathrm{Pb}, \mathrm{Hg}, \mathrm{Cr}$ and $\mathrm{Co}$, etc. enter into the soil, water and plants and cause environmental pollutions and poison food chain [1-4]. So, in the viewing of health risk hazards, determination of heavy metals in environmental samples is very important [5-7].

The hexavalent chromium has a serious environmental pollution and threatens human health [8]. Chromium species exist mainly in two different oxidation states in

\section{Biomed Central}


the environment, $\mathrm{Cr}$ (III) and $\mathrm{Cr}$ (VI), which have contrasting physiological effects. The Cr (III) compounds play an important role in the metabolism of glucose and certain lipids $[9,10]$. On the contrary, the $\mathrm{Cr}(\mathrm{VI})$ has toxic and carcinogenic effects and damage macromolecules, proteins and DNA [11]. The World Health Organization (WHO) states that $50 \mu \mathrm{g} / \mathrm{L}$ of $\mathrm{Cr}(\mathrm{VI})$ are considered to be too high as compared to its gen-toxicity [11-13]. Exposure may occur from natural or industrial sources of chromium. The general population is exposed to chromium by inhaling ambient air, ingesting food, and drinking water containing chromium. WHO has set a permissible limit of $0.05 \mathrm{mg} / \mathrm{L}$ for total chromium in drinking water [14]. Thus, the accurate determination of chromium ions has become increasingly necessary to study problems associated with environmental water pollution.

In order to provide a timely warning of chromium exposure, it is highly desirable to develop suitable procedures for chromium speciation. The most sensitive analysis techniques for determination of chromium species include ion chromatography inductively coupled plasma mass spectrometry (IC-ICP-MS) [15], luminescence quenching [16], stripping voltammetry [17], flame atomic absorption spectrometry (F-AAS) [18], neutron activation analysis (NAA) [19], inductively coupled plasma optical emission spectrometry (ICP-OES) [20], isotopedilution mass spectrometry (ID-MS) [21], and electrothermal atomic absorption spectrometry (ET-AAS) [22, 23]. However, high instrumental and operational costs, low concentration levels of analytes, high levels of matrices, and high detection limits are common disadvantages of many of these methods. In order to simplify the analytical approaches, a separation/preconcentration step prior to analysis is required. Liquid-liquid extraction (LLE) [24, 25], homogeneous liquid-liquid extraction [26], solid phase extraction (SPE) [27, 28], liquid-phase microextraction (LPME) [29], and cloud point extraction (CPE) [30], etc., have been used for the preconcentration and/or separation of trace and ultra-trace amounts of chromium.

Among variety of methods, SPE is widely applied for the trace metal ions preconcentration because of its advantages including simplicity, minimal cost, rapidity, safety and ease of automation, lesser waste generation, lesser matrix effect, availability and easy recovery, high preconcentration efficiency, and easy adaptation of solid phase in a mini column coupled to a continuous flow preconcentration system [31]. In the SPE procedure, the choice of the appropriate sorbent is a critical factor to obtain full recovery and a high preconcentration factor. Many adsorbents such as activated carbons, nano sulfur, composite materials $(\mathrm{CM})$, mesoporous silicate materials, and mesoporous silicate nanoparticles (MSN) have been successfully used for this purpose.
Since 1992, mesoporous silicate materials, especially MCM-41, have been received growing attention because of their unique properties such as high surface area and tunable pore size which facilitate the diffusion of large reactants and products inside the pores [32, 33]. These properties allow easy access of functional groups $(\mathrm{R}=$ $\mathrm{OH}, \mathrm{CN}, \mathrm{S}, \mathrm{NH}_{2}$ ) into the structure, which increases the adsorption capacity due to the combination of chemical and physical adsorption processes [34]. The mesoporous silicate nanoparticles (MSN) have higher surface area and therefore higher physical adsorption than mesoporous silicate materials [35]. The properties of MSN have been investigated by many research groups in many fields such as catalysis [35], separation [36], optic [37], biotechnology [38-40], and selective adsorbents. These nanomaterials are widely used as adsorbents for adsorption of heavy metal ions from aqueous solution in the field of water treatment [41, 42]. UVM-7 is an interesting material which can be considered as a nanometric version of the well-known MCM-41 material, and the most outstanding feature of this material is its peculiar architecture: a continuous network constructed from aggregates formed from connected mesoporous silicate nanoparticles in the range of meso/macropores, and so it has a bimodal pore system [43].

In this study, UVM-7 as bimodal mesoporous nanoparticle was synthesized and subsequently functionalized with amino silane via grafting method. The main purpose of the present research is to develop a novel analytical method for speciation and preconcentration of trace amounts of $\mathrm{Cr}(\mathrm{VI}) / \mathrm{Cr}$ (III) ions in water samples without the application of any chelating agents. The method is based on the combination of $\mathrm{NH}_{2}$-UVM7-packed micro-column SPE and F-AAS detection method. To the best of our knowledge, no attempt has been made to apply $\mathrm{NH}_{2}$-UVM-7 in SPE procedure for preconcentration of heavy metal ions, especially for speciation of $\mathrm{Cr}$ ions, in water samples. All main factors for the quantitative recoveries of $\mathrm{Cr}$ ions were investigated and optimized. The developed method was successfully applied for speciation and determination of analytes in real water samples. Also, the synthesized adsorbent can be used for removal of $\mathrm{Cr}(\mathrm{VI})$ ions from water samples.

\section{Methods}

\section{Apparatus and materials}

The determination of chromium ions was performed using spectra GBC flame atomic absorption spectrometer (F-AAS, GBC, Plus 932, Australia) under the conditions given by the manufacturer with air-acetylene flame and deuterium background correction. A Cr hollow cathode lamp operating at a current of $6 \mathrm{~mA}$ and a wavelength of $357.9 \mathrm{~nm}$ with a spectral bandwidth of $0.2 \mathrm{~nm}$ was used. The instrumental conditions were 
listed in Table 1 . The $\mathrm{pH}$ values were measured with a Metrohm pH-meter (model 744, Herisau, Switzerland). A peristaltic pump (Lambda, Switzerland) was used in the SPE process.

All chemical compounds and reagents used for experiments and analysis were of analytical grade and purchased from Merck (Darmstadt, Germany). Cr (III) stock solution was prepared by dissolving of appropriate amount of $\mathrm{Cr}\left(\mathrm{NO}_{3}\right)_{3} .9 \mathrm{H}_{2} \mathrm{O}$ (Merck,) as $1000 \mathrm{mg} \mathrm{L}^{-1}$ solution in $1 \% \mathrm{HNO}_{3}$. $\mathrm{Cr}$ (VI) stock solution was prepared by dissolving of appropriate amount of $\mathrm{K}_{2} \mathrm{Cr}_{2} \mathrm{O}_{7}$ (Merck) as $1000 \mathrm{mg} \mathrm{L}^{-1}$ solution in $1 \% \mathrm{HCl}$. Standard and experimental solutions were prepared daily by dilution of the stock solution. The $\mathrm{pH}$ adjustments of samples were made using nitric acid (0.1 mol/L) for $\mathrm{pH} 1-2$, and appropriate buffer solutions including sodium acetate $\left(\mathrm{CH}_{3} \mathrm{COONa} / \mathrm{CH}_{3} \mathrm{COOH}, 1-2 \mathrm{~mol} / \mathrm{L}\right)$ for $\mathrm{pH} 3-7$, and ammonium chloride $\left(\mathrm{NH}_{3} / \mathrm{NH}_{4} \mathrm{Cl}, 0.2 \mathrm{~mol} / \mathrm{L}\right)$ for $\mathrm{pH}$ 8-10. Deionized water obtained from a Millipore Continental Water System (Bedford, MA, USA) was used throughout this study. All the laboratory glassware and plastics were cleaned by soaking in $10 \%(\mathrm{v} / \mathrm{v})$ nitric acid for at least $24 \mathrm{~h}$ and then rinsed with deionized water prior to use.

\section{Synthesis and functionalization of UVM-7}

The general procedure for synthesis of UVM-7 is the atrane route, in which the presence of the polyalcohol is the key to balancing the hydrolysis and condensation reaction rates. In a typical synthesis, TEOS (tetraethyl ortho-silicate) was added to predetermine amounts of $\mathrm{TEAH}_{3}$ (triethanolamine). The solution was heated up to $140{ }^{\circ} \mathrm{C}$ under vigorous stirring. After cooling down to $90{ }^{\circ} \mathrm{C}, \mathrm{CTAB}$ (cetyltrimethylammonium bromide) was added to this solution. Hereafter, water was added slowly to the solution under stirring until a white suspension was obtained. This suspension was kept for $4 \mathrm{~h}$ at room temperature. The solid was filtered, washed with sufficient amounts of water and acetone and dried in an oven at $80{ }^{\circ} \mathrm{C}$ overnight. Thermocalcination of the assynthesized UVM-7 was carried out under flow of air up

Table 1 Instrumental conditions for chromium determination by F-AAS

\begin{tabular}{ll}
\hline Parameters & F-AAS \\
\hline Wavelength & $357.9 \mathrm{~nm}$ \\
Slit & $0.2 \mathrm{~nm}$ \\
Lamp curent & $6 \mathrm{~mA}$ \\
Injection mode & Manual \\
Volume Injection & $2.2 \mathrm{~mL} / \mathrm{min}$ \\
Mode & Integration \\
Fuel & Air-Acetylene \\
\hline
\end{tabular}

to $550{ }^{\circ} \mathrm{C}$ for $6 \mathrm{~h}$ with a heating rate of $1{ }^{\circ} \mathrm{C} / \mathrm{min}$ to remove both the surfactant and $\mathrm{TEAH}_{3}$ from the as-synthesized UVM-7. The final molar composition of the reactants was 1.0 TEOS: $3.5 \mathrm{TEAH}_{3}: 0.25$ CTAB: 90 $\mathrm{H}_{2} \mathrm{O}$.

For the functionalization of calcined UVM-7 with amine groups, $1.2 \mathrm{~g}$ of triethoxysililpropylamine $\left(\mathrm{C}_{9} \mathrm{H}_{23} \mathrm{NO}_{3} \mathrm{Si}\right)$ and $2 \mathrm{~g}$ of calcined UVM-7 were added to appropriate amount of toluene and refluxed for $24 \mathrm{~h}$ at $80{ }^{\circ} \mathrm{C}$, followed by filtering and washing with proper amounts of ethanol and deionized water. The obtained bulky aminefunctionalized UVM-7 was dried at $80{ }^{\circ} \mathrm{C}$ overnight.

\section{Characterization of adsorbent}

X-ray diffraction (XRD) patterns were recorded on a Seifert TT 3000 diffractometer (Ahrensburg, Germany) using nickel filtered $\mathrm{Cu}-\mathrm{K} \alpha$ radiation of wavelength $0.15405 \mathrm{~nm}$. The textural properties of the sorbent including surface area, pore volume, and pore size distribution were determined by nitrogen adsorption-desorption isotherms at- $196{ }^{\circ} \mathrm{C}$ using BELSORP-mini porosimeter (Bell Japan, Inc.). Prior to analysis the samples were degassed under vacuum at $300{ }^{\circ} \mathrm{C}$ for $4 \mathrm{~h}$ until a stable vacuum of $0.1 \mathrm{~Pa}$ was reached. The specific surface areas and pore volume of the sorbents were calculated by the BrunauerEmmett-Teller (BET) and Barrett-Joyner-Halenda (BJH) methods, respectively. Scanning electron microscopy (SEM, Phillips, PW3710, Netherland) was used for surface image analysis of the sorbents. The morphology of sorbent was examined by transmission electron microscopy (TEM, CM30, Philips, Netherland). The elemental analyzer (CHNS/O, PerkinElmer, 2400 Series II, USA) was used for determination of elemental composition of sample. $\mathrm{CHN}$ instrument performs elemental ratio calculations of $\mathrm{H} / \mathrm{C}, \mathrm{N} / \mathrm{C}, \mathrm{S} / \mathrm{C}$ or $\mathrm{C} / \mathrm{N}$.

\section{General procedure}

In SPE procedure, thin wall polymer tubing with outer diameter of $0.55 \mathrm{~cm}$, inner diameter of $0.5 \mathrm{~cm}$, length of $5 \mathrm{~cm}$, and wall thickness of $0.05 \mathrm{~cm}$ filled by bulky nanoparticles of $\mathrm{NH}_{2}-\mathrm{UVM}-7$ was used as a preconcentration micro-column. An aliquot of the sample solution $(100 \mathrm{~mL})$ containing $20 \mu \mathrm{g} / \mathrm{L}$ of $\mathrm{Cr}$ (VI) and/or Cr (III) was adjusted to $\mathrm{pH}=2$ with nitric acid solution $(0.1 \mathrm{~N})$. The resulting sample solution was pumped through the $\mathrm{NH}_{2}-\mathrm{UVM}-7$ packed micro-column at a flow rate of $2.5 \mathrm{~mL} / \mathrm{min}$. The micro-column was then rinsed with $5 \mathrm{~mL}$ deionized water. Afterwards, the retained $\mathrm{Cr}$ (VI) ions were completely eluted from the solid phase with $1.5 \mathrm{~mL}$ of $0.3 \mathrm{~mol} / \mathrm{L}$ $\mathrm{NaOH}$ solution. Finally, the concentration of $\mathrm{Cr}$ (VI) ions in the eluent was determined by F-AAS. The recovery was calculated by using Eq. 1 , where $C_{i}$ is the initial concentrations of analytes in solution phase, and $C_{f}$ is the concentration of analytes determined by F-AAS after the SPE 
process. All the experimental data were the averages of triplicate determinations.

$$
\text { Recovery } \%=\frac{\left(\mathrm{C}_{\mathrm{i}}-\mathrm{C}_{\mathrm{f}}\right)}{\mathrm{Ci}} \times 100
$$

In the optimum $\mathrm{pH}$ conditions, $\mathrm{Cr}(\mathrm{VI})$ ions were complexed with amine groups of $\mathrm{NH}_{2}-\mathrm{UVM}-7$ and total chromium was calculated by oxidation of $\mathrm{Cr}$ (III) to $\mathrm{Cr}(\mathrm{VI})$ with $\mathrm{H}_{2} \mathrm{O}_{2}$ solution $(1 \mathrm{~mL}, 0.2 \mathrm{M})$. Then, $\mathrm{Cr}$ (III) concentration of water sample was simply calculated by the difference between total chromium and $\mathrm{Cr}$ (VI) concentrations. A blank solution was also run under the same analytical conditions without adding any chromium ions. The $\mathrm{NH}_{2}-\mathrm{UVM}-7$ adsorbent was used freshly for blank experimental run. Moreover, the same procedure was repeated for unmodified UVM-7 sorbent. The extraction conditions were listed in Table 2.

\section{Results}

XRD analysis

XRD patterns of calcined UVM-7 and amine-grafted UVM-7 are shown in Fig. 1. There are three resolved diffraction peaks in XRD patterns of $\mathrm{NH}_{2}-\mathrm{UVM}-7$ and UVM-7, which can be indexed as the (100), (110), (200) and (210) reflections associated with hexagonal symmetry $\left(d_{110}\right.$ and $d_{200}$ were overlapped with each other). However, these peaks are broad, which is the characteristic of mesoporous materials synthesized via atrane route. After the attachment of organic groups on the silica wall of UVM-7, the main three diffraction peaks are still clear which means that functionalization procedure did not had worth effect on the structural order of UVM-7.

Table 2 Extraction Conditions of proposed method for chromium speciation

\begin{tabular}{ll}
\hline Parameter & Value \\
\hline Working $\mathrm{pH}$ & 2 \\
Amount of $\mathrm{NH}_{2}$-UVM-7 & $0.12 \mathrm{~g}$ \\
Sample volume of SPE & $100 \mathrm{~mL}$ \\
Volume of sample injection & $1.5 \mathrm{~mL}$ \\
Linear range (method) & $6-320 \mu \mathrm{g} / \mathrm{L}$ \\
Limit of detection (LOD) & $1.2 \mu \mathrm{g} / \mathrm{L}$ \\
Preconcentration factor (PF) & 66.7 \\
Buffer concentration & $0.03 \mathrm{~mol} / \mathrm{L}$ \\
Volume of back-extraction solvent $(\mathrm{NaOH})$ & $1.5 \mathrm{~mL}$ \\
Concentration of back-extraction solvent $(\mathrm{NaOH})$ & $0.3 \mathrm{~mol} / \mathrm{L}$ \\
Linear range (F-AAS) & $0.4-15 \mathrm{mg} / \mathrm{L}$ \\
Correlation coefficient of F-AAS & $\mathrm{R}^{2}=0.9956$ \\
\hline
\end{tabular}

\section{$\mathrm{N}_{2}$ physisorption}

The nitrogen adsorption-desorption isotherms of UVM7 and $\mathrm{NH}_{2}$-UVM-7 were determined and displayed in Fig. 2. The corresponding isotherm of both samples displays two distinct regions at medium and at high relative pressure which can be attributed to the presence of bimodal pore system. The first is related to the presence of small mesopores (IUPAC clacification), and the second is related to the large mesopores, respectively. The observation of these two distinct regions in both the samples, UVM-7 and $\mathrm{NH}_{2}$-UVM-7, confirms that the UVM-7 bimodal pore system is remained almost intact after the functionalization with triethoxysililpropylamine. Textural properties of UVM-7 and NH2-UVM-7 were determined and presented in Table 3. The specific surface area $\left(\mathrm{S}_{\mathrm{BET}}\right)$ of UVM-7 and $\mathrm{NH}_{2}$-UVM-7 calculated from the linear part of the BET equation were $863 \mathrm{~m}^{2} / \mathrm{g}$ and $626 \mathrm{~m}^{2} / \mathrm{g}$, respectively. Decreasing of BET surface area, pore volume, and pore diameter of $\mathrm{NH}_{2}$-UVM-7 in comparison with initial UVM-7 is due to the grafting of aminosilane on silica walls. The unit cell parameter $\left(\mathrm{a}_{0}\right)$ and the average pore wall thickness $\left(\mathrm{W}_{\mathrm{t}}\right)$ of the sorbents were calculated by the equations of $a_{0}=2 \cdot d_{100} / \sqrt{ } 3$ and $\mathrm{W}_{\mathrm{t}}=\mathrm{a}_{0}-\left(\mathrm{d}_{\mathrm{p}} / 1.05\right)$, respectively, where $\mathrm{d}_{\mathrm{p}}$ is the pore diameter of adsorbent and $d_{100}$ is obtained from XRD diffractograms. As shown in Table 3, these two parameters are almost constant for both the sorbents.

\section{Elemental analysis}

Elemental analysis provides further evidence for the amount of amine functional groups grafteed on UVM-7. The yield of functionalization can be calculated using the elemental analysis results (the ratio of nitrogen content of the amine-functionalized UVM-7 divided by the amount of nitrogen of the triethoxysililpropylamine used for functionalization). The nitrogen content was $4.83 \mathrm{wt} \%$. Moreover, by determining the nitrogen content of the remaining toluene it was found that about $99 \%$ of the triethoxysililpropylamine was grafted on the UVM-7.

\section{SEM imaging}

The SEM was performed to illustrate the morphology and particle size distribution of the calcined $\mathrm{NH}_{2}$-UVM7. As shown in Fig. 3, $\mathrm{NH}_{2}$-UVM-7 has a highly porous morphology and the mesoporous silica particles are in nanometer range $(30 \mathrm{~nm})$. Moreover, functionalization did not led to bulky silica nanoparticles.

\section{TEM imaging}

TEM image also illustrates pore structure of $\mathrm{NH}_{2}$-UVM-7. As shown in Fig. 4, the mesopores are clearly visible in the silica nanoparticles and particle size of the samples is in 


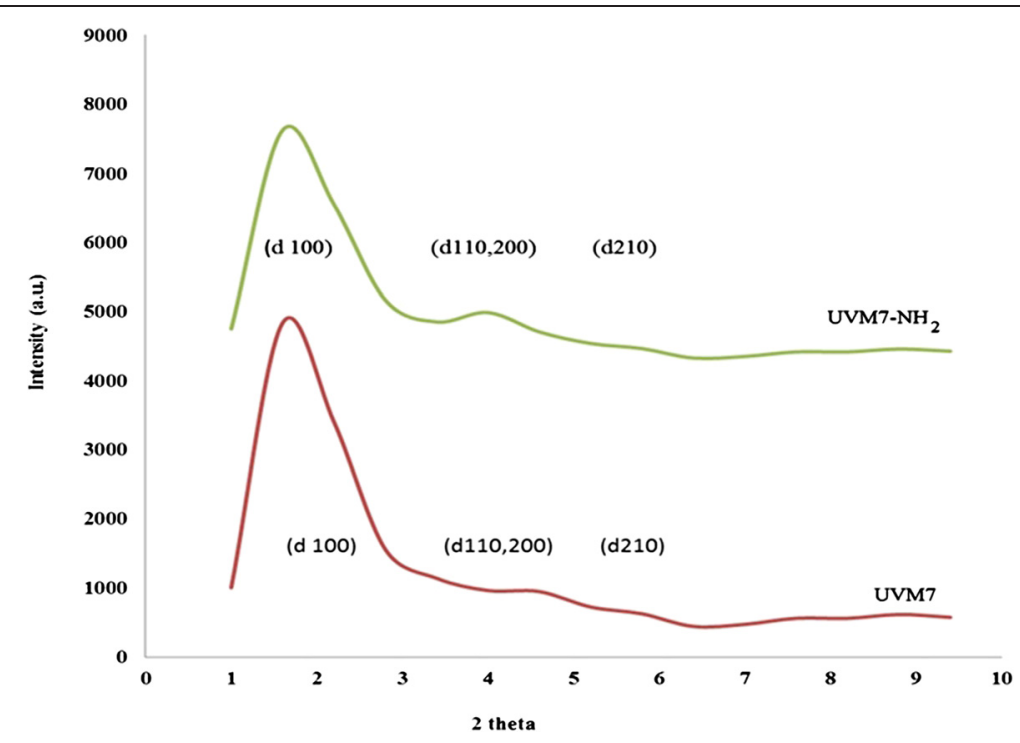

Fig. 1 Low angle XRD patterns of calcined $\mathrm{NH}_{2}-U V M-7$ and UVM-7

nanometer range around 30 to $40 \mathrm{~nm}$ as those observed in SEM image.

\section{Effect of $\mathrm{pH}$, sample volume and amount of $\mathrm{NH}_{2}-\mathrm{UVM}-7$} In the SPE studies, the $\mathrm{pH}$ of the sample solution is an important parameter to obtain quantitative recoveries of metal ions, because it affects the surface charge of the adsorbent, the degree of ionization and speciation of the adsorbate. The influence of sample $\mathrm{pH}$ on speciation and recovery efficiency of $\mathrm{Cr}$ (VI)/Cr (III) ions by $\mathrm{NH}_{2}-$ UVM-7 was investigated at different $\mathrm{pH}$ values $(1-10)$ by using buffered sample solutions containing $\mathrm{Cr}$ (III) and $\mathrm{Cr}$ (VI) ions, according to the general procedure. The complexation was strongly conditioned by the $\mathrm{pH}$ of solutions and subsequently affects extraction efficiency of the complex. As shown in Fig. 5, the highest extraction efficiency (>97 \%) for $\mathrm{Cr}$ (VI) was achieved in the $\mathrm{pH}$ range of $1-3.2$, whereas the recovery values for $\mathrm{Cr}$ (III) were below $5 \%$ in the same $\mathrm{pH}$. Thus, the procedure was applied to speciation of $\mathrm{Cr}(\mathrm{VI}) / \mathrm{Cr}$ (III) ions at $\mathrm{pH}=2$. For higher $\mathrm{pH}$ values $(\mathrm{pH}>3)$, the recovery percentages of $\mathrm{Cr}(\mathrm{VI})$ ions decreased with increase in $\mathrm{pH}$.

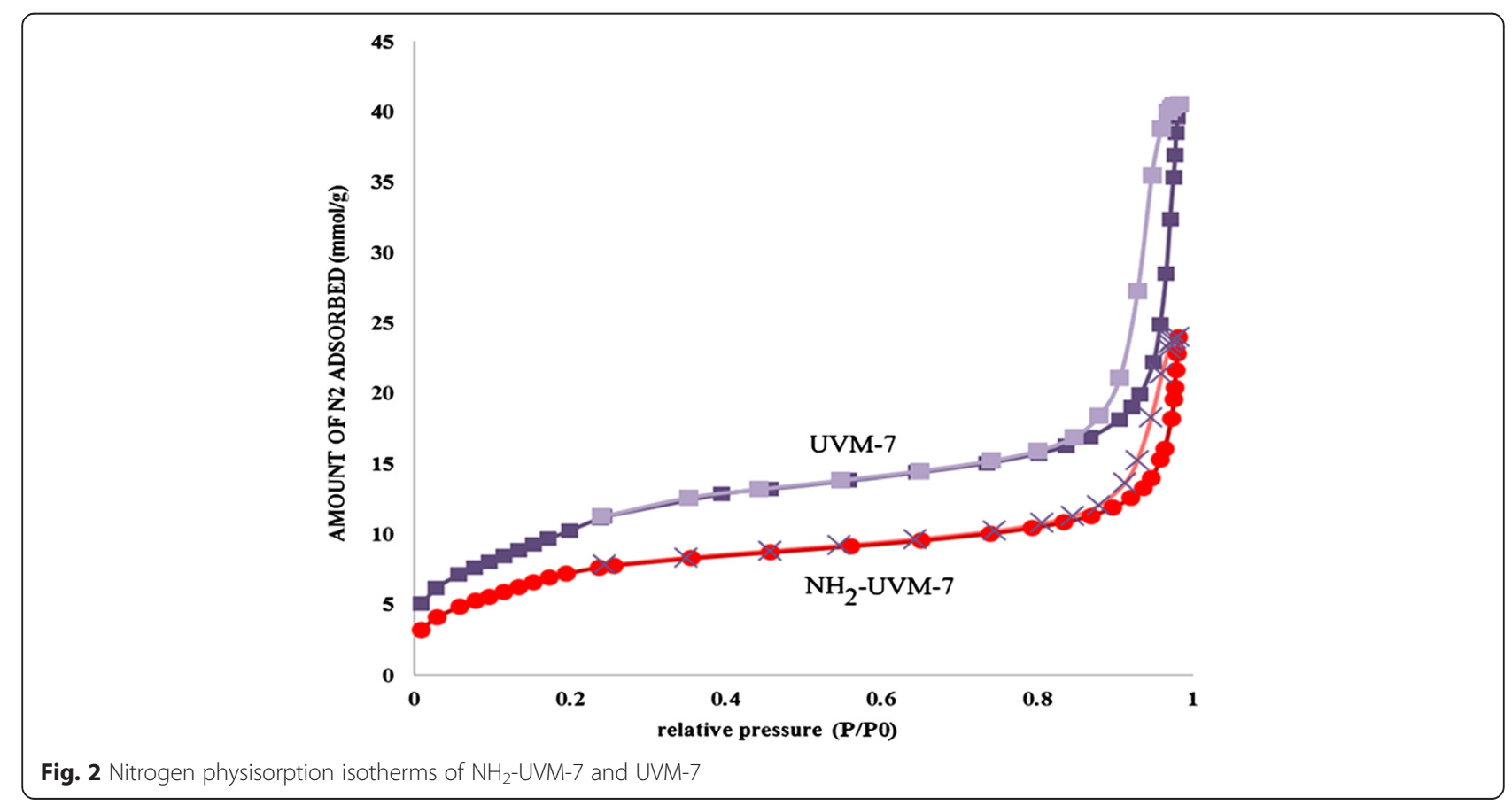


Table 3 Textural properties of UVM-7 and $\mathrm{NH}_{2}-\mathrm{UVM}-7$

\begin{tabular}{llllllll}
\hline Sample & $\mathrm{S}_{\text {BET }}^{\mathrm{e}}\left(\mathrm{m}^{2} / \mathrm{g}\right)$ & $\mathrm{d}_{\mathrm{sp}}^{\mathrm{b}}(\mathrm{nm})$ & $\mathrm{d}_{\mathrm{lp}}^{\mathrm{c}}(\mathrm{nm})$ & $\mathrm{V}_{\mathrm{sp}}^{\mathrm{d}}\left(\mathrm{cm}^{3} / \mathrm{g}\right)$ & $\mathrm{V}_{\mathrm{lp}}^{\mathrm{e}}\left(\mathrm{cm}^{3} / \mathrm{g}\right)$ & $\mathrm{a}^{\mathrm{f}}(\mathrm{nm})$ & $\mathrm{W}_{\mathrm{t}}{ }^{\mathrm{g}}(\mathrm{nm})$ \\
\hline UVM-7 & 863 & 2.67 & 52.2 & 0.42 & 0.84 & 5.59 & 2.92 \\
$\mathrm{NH}_{2}$-UVM-7 & 626 & 2.62 & 42.2 & 0.27 & 0.41 & 5.59 & 2.97 \\
\hline
\end{tabular}

${ }^{\mathrm{a} B E T}$ specific surface area, ${ }^{\mathrm{b}}$ diameter of small pores, ${ }^{\mathrm{c}}$ diameter of large pores, ${ }^{\mathrm{d}}$ Volume of small pores, ${ }^{\mathrm{e}}$ Volume of large pores, ${ }^{\mathrm{f}}$ Unit cell parameter obtained from XRD diffractograms $\left(2 d_{100} / \sqrt{ } 3\right),{ }^{g}$ Wall thickness $(n m)$ obtained by following equation: $\mathrm{W}_{\mathrm{t}}=\mathrm{a}-\left(\mathrm{d}_{\mathrm{p}} / 1.05\right)$

The extraction mechanism of $\mathrm{Cr}(\mathrm{VI})$ ions on the $\mathrm{NH}_{2}-$ UVM-7 may be based on the electrostatic attractions between metals ions and $\mathrm{NH}_{2}$ groups of nanoadsorbent, which is highly dependent on solution $\mathrm{pH}$. The $\mathrm{NH}_{2}$ groups on the surface of the $\mathrm{NH}_{2}$-UVM-7 can either be protonated $\left(-\mathrm{NH}_{3}^{+}\right)$at low $\mathrm{pH}$ or be deprotonated $\left(\mathrm{NH}^{-}\right)$ at high $\mathrm{pH}$. The variation in adsorption capacity of $\mathrm{Cr}$ (VI) at different $\mathrm{pH}$ values may be attributed to the affinities of $\mathrm{NH}_{2}$-UVM-7 nanoadsorbent for the different anionic species of $\mathrm{Cr}$ (VI) existing at acidic $\mathrm{pH}$ conditions namely $\mathrm{HCrO}_{4}^{-}, \mathrm{CrO}_{4}^{2-}$ and $\mathrm{Cr}_{2} \mathrm{O}_{7}^{2-}$. It is clear that negatively charged $\mathrm{HCrO}_{4}^{-}$and $\mathrm{Cr}_{2} \mathrm{O}_{7}^{2-}$ are easily adsorbed to the positively charged $\mathrm{NH}_{3}^{+}$at low $\mathrm{pH}$ values due to the electronic attraction. By using UVM-7 as the SPE adsorbent for preconcentration of $\mathrm{Cr}$ (IV) ions, it was observed that the extraction efficiencies were less than $5 \%$ in the studied $\mathrm{pH}$ range. This is because the physical adsorption of $\mathrm{Cr}$ (VI) ions by unmodified UVM-7 is the main mechanism. So, the $\mathrm{NH}_{2}-\mathrm{UVM} 7$ is favorite adsorbent for speciation and determination of $\mathrm{Cr}(\mathrm{VI}) / \mathrm{Cr}$ (III) ions in water samples by SPE method and can be used for on-line removal $\mathrm{Cr}$ (VI) in water samples at $\mathrm{pH}=2$.

Sample volume is one of the most important parameters of SPE procedure. The effect of aqueous sample volume on the recoveries of analyte ions was examined by passing different volumes $(10-200 \mathrm{~mL})$ of sample solution from the micro-column, according to the general procedure. The results were illustrated in Fig. 6 .

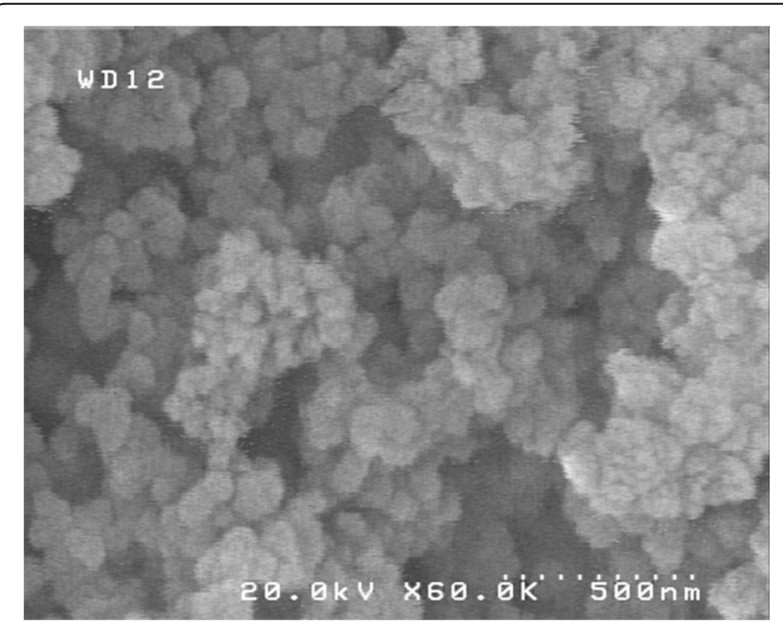

Fig. 3 SEM image of $\mathrm{NH}_{2}-U V M-7$
Quantitative recoveries of $\mathrm{Cr}(\mathrm{VI})$ ions were obtained using 10-100 $\mathrm{mL}$ of sample solution. At higher volumes, the recoveries were decreased. Therefore, $100 \mathrm{~mL}$ was selected as the optimum sample volume for further experiments of SPE. The preconcentration factor (PF) for preconcentration and extraction is calculated by the ratio of the highest sample volume for analyte $(100 \mathrm{~mL})$ and the lowest final eluent volume $(1.5 \mathrm{~mL})$. In the present study the possible preconcentration factor was 66.7.

The effect of the adsorbent dosage on the recoveries of $\mathrm{Cr}(\mathrm{VI})$ ions was investigated using various amounts of $\mathrm{NH}_{2}-\mathrm{UVM}-7$ in the range of $0.03-0.2 \mathrm{~g}$ (Fig. 7). It was observed that the extraction efficiency of the system was remarkably affected by $\mathrm{NH}_{2}$-UVM-7 amount, and quantitative extraction was obtained using 0.1-0.2 $\mathrm{g}$ of $\mathrm{NH}_{2}$-UVM-7. Therefore, in order to achieve a suitable preconcentration, $0.12 \mathrm{~g}$ of $\mathrm{NH}_{2}-\mathrm{UVM}-7$ was chosen as optimum leading to a final adsorbent.

\section{Effect of matrix and various eluents}

In this section, the interfering effect of various matrix ions, most probably present in the environmental samples, on the recoveries of $\mathrm{Cr}$ (VI) ions from $\mathrm{NH}_{2}$-UVM7 based SPE was examined. The procedure of SPE was performed using a $100 \mathrm{ml}$ sample containing $100 \mu \mathrm{g} / \mathrm{L}$ of analyte and 1-2 $\mathrm{mg} / \mathrm{L}$ of different concentration of matrix ions. The tolerate amounts of each ion were the concentration values tested that caused less than $5 \%$ the absorbance alteration. As shown in Table 4, the ions

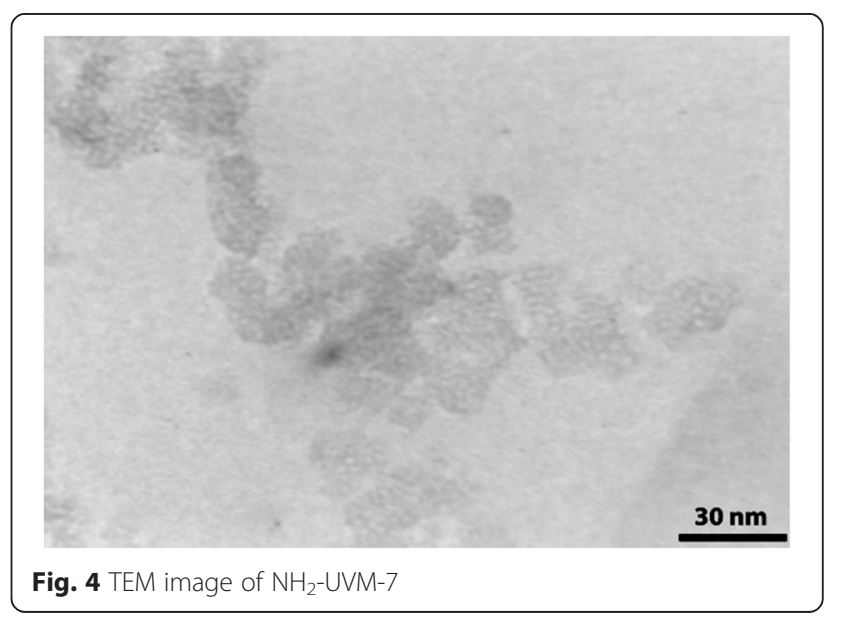




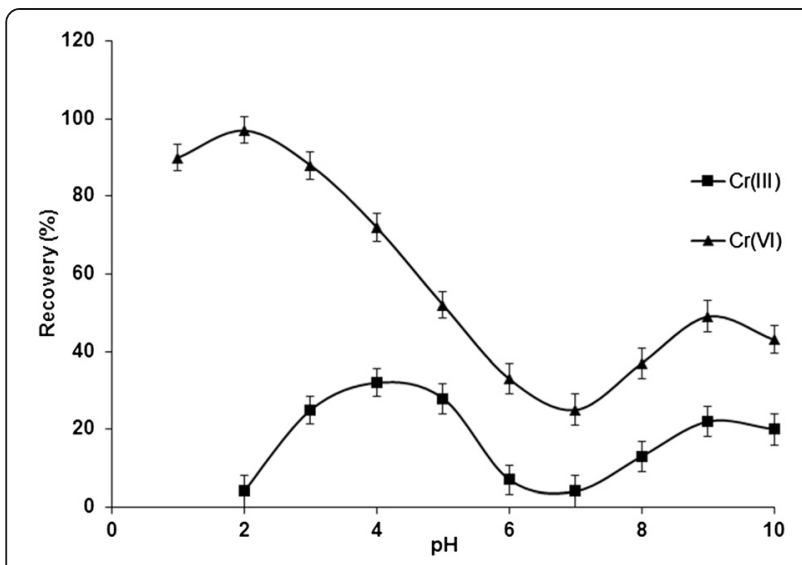

Fig. 5 The influence of solution $\mathrm{pH}$ on the recovery of $\mathrm{Cr}(\mathbf{V I})(\mathbf{\Delta})$ and $\mathrm{Cr}(\mathrm{III})(\mathbf{-})$ ions with $\mathrm{NH}_{2}-\mathrm{UVM}-7(\boldsymbol{\Delta})$. Conditions: sample volume $100 \mathrm{~mL}$; adsorbent amount $0.12 \mathrm{~g}$; eluent $1.5 \mathrm{~mL}$ of $0.3 \mathrm{~mol} / \mathrm{L} \mathrm{NaOH}$; sample flow rate $2.5 \mathrm{~mL} / \mathrm{min}$

normally present in natural waters has no significant influence on the adsorption of $\mathrm{Cr}$ (VI) ions under the experimental conditions used.

The proposed method was based on back-extraction of $\mathrm{Cr}$ (VI) ions from $\mathrm{NH}_{2}$-UVM-7 with a suitable basic elution solution. Increasing of the $\mathrm{pH}$ leads to dissociation and releasing of chromium ions into the aqueous phase. A volume of $1.5 \mathrm{~mL}$ of various eluents such as $\mathrm{NaOH}, \mathrm{NH}_{3}$, and $\mathrm{EtOH}$ (ethanol) with different concentration of $0.2-1 \mathrm{~mol} / \mathrm{L}$ were tested as the eluent. The results showed that $1.5 \mathrm{~mL}$ of $0.3 \mathrm{~mol} / \mathrm{L} \mathrm{NaOH}$ quantitatively extracted chromium ions from the solid phase. At high concentration of $\mathrm{NaOH}$, the recovery percentage was decreased (Fig. 8).

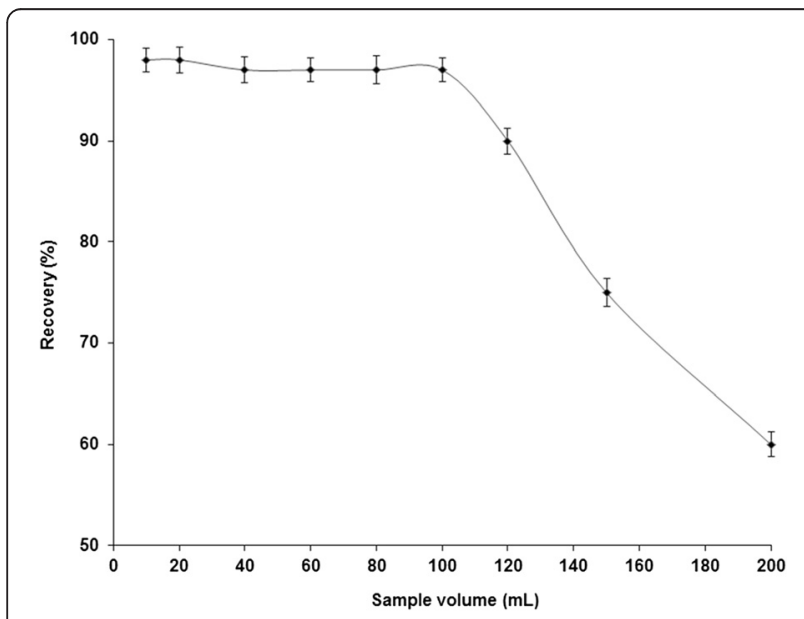

Fig. 6 The influence of sample volume on the recovery of $\mathrm{Cr}(\mathbf{V I})$ ions. Conditions: solution $\mathrm{pH} 2$; adsorbent amount $0.12 \mathrm{~g}$; eluent $1.5 \mathrm{~mL}$ of $0.3 \mathrm{~mol} / \mathrm{L} \mathrm{NaOH}$; sample flow rate $2.5 \mathrm{~mL} / \mathrm{min}$

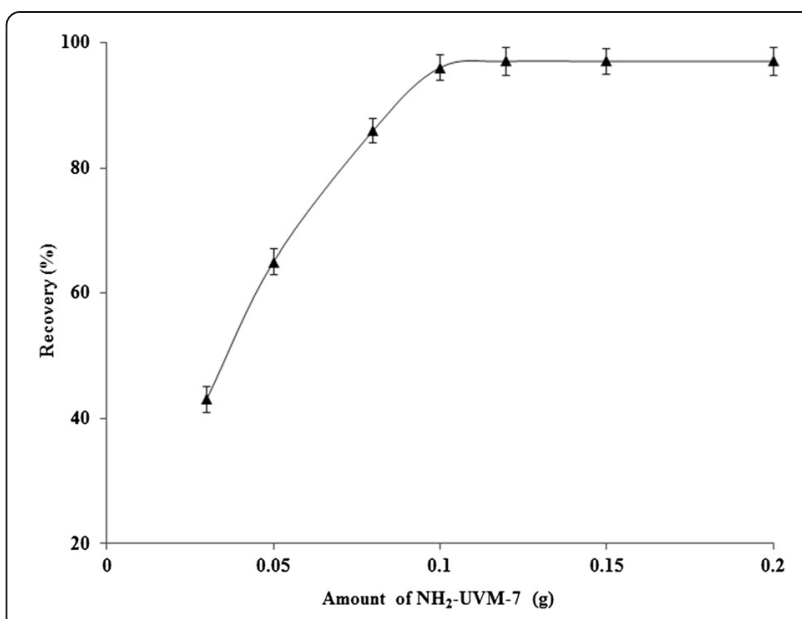

Fig. 7 The influence of amount of $\mathrm{NH}_{2}-U V M-7$ on the recovery of $\mathrm{Cr}$ (VI) ions. Conditions: sample volume $100 \mathrm{~mL}$; solution $\mathrm{pH}$ 2; eluent $1.5 \mathrm{~mL}$ of $0.3 \mathrm{~mol} / \mathrm{L} \mathrm{NaOH}$; sample flow rate $2.5 \mathrm{~mL} / \mathrm{min}$

\section{Method validation}

The developed method was applied for speciation/preconcentration and determination of $\mathrm{Cr}$ (VI) and $\mathrm{Cr}$ (III) ions in different water samples including Tap and drinking water (Tehran, Iran), river water (Kan, Tehran, Iran), waste water (petrochemical factory, Tehran, Iran) and industrial water (Tehran, Iran). The spiked samples were prepared to demonstrate the accuracy and reliability of the method for determination of $\mathrm{Cr}$ (III) and $\mathrm{Cr}$ (VI). The remaining aliquots were spiked with increasing quantities of $\mathrm{Cr}$ (VI) and $\mathrm{Cr}$ (III) and analyzed by the developed SPE method. As it can be seen from Table 5, a good agreement was obtained between the added and measured analytes amount, which confirms the accuracy of the procedure and its independence from the matrix effects. The recovery of spiked samples is satisfactorily reasonable and was confirmed using addition method, which indicates the capability of the system in the determination of $\mathrm{Cr}$ (VI) and $\mathrm{Cr}$ (III) in water and biological samples. The validation of the presented procedure was also performed by the analysis of certified reference material, NIST SRM 1643e (Trace elements in water), from the National Institute of Standard and Technology (NIST, Gaithersburg, USA), for chromium values. The results found were in good agreement with the certified values of SRM (Table 6).

\section{Adsorption capacity}

The adsorption capacity of $\mathrm{NH}_{2}$-UVM-7 was determined for $\mathrm{Cr}$ (VI) by using column technique. $100 \mathrm{~mL}$ of aqueous solutions containing $5-500 \mathrm{mg} / \mathrm{L} \mathrm{Cr}$ (VI) at optimized $\mathrm{pH}$ were passed through a micro-column filled with $0.12 \mathrm{~g}$ of $\mathrm{NH}_{2}-\mathrm{UVM}-7$ at a flow rate of $0.5-5 \mathrm{ml} /$ min. After $\mathrm{Cr}(\mathrm{VI})$ was eluted from the nanosorbent with $1.5 \mathrm{~mL}$ of $\mathrm{NaOH}(0.3 \mathrm{~mol} / \mathrm{L})$, the concentration of $\mathrm{Cr}$ 
Table 4 The effect of matrix ions on chromium speciation and determination by proposed method

\begin{tabular}{ll}
\hline lons & $\begin{array}{l}\text { Maximum tolerance ratio } \\
\text { (matrix ion conc./Cr conc.) }\end{array}$ \\
\hline $\mathrm{Ni}^{2+}, \mathrm{Mg}^{2+}, \mathrm{Ca}^{2+}, \mathrm{Co}^{2+}, \mathrm{Al}^{3+}, \mathrm{K}^{+}, \mathrm{Na}^{+}$, & 2000 \\
$\mathrm{~V}^{3+}, \mathrm{Mn}^{2+}, \mathrm{Fe}^{3+}, \mathrm{Pb}^{2+}, \mathrm{Zn}^{2+}$ & \\
$\mathrm{PO}_{4}^{3-}, \mathrm{Cl}^{-}, \mathrm{CO}_{3}^{2-}, \mathrm{SO}_{4}^{2-}, \mathrm{NO}_{3}^{-}$ & 1000 \\
\hline This work was performed using $100 \mathrm{~mL}$ of $100 \mu \mathrm{gg} / \mathrm{L} \mathrm{Cr}(\mathrm{Vl})$ standard solution
\end{tabular}

(VI) in eluent was determined by F-ASS. In order to successfully represent the dynamic adsorptive behaviour, it is important to have a satisfactory description of the equation state between the two phases composing the adsorption system. In this study the Langmuir adsorption isotherm was employed for $\mathrm{Cr}(\mathrm{VI})$ adsorption by $\mathrm{NH}_{2}$-UVM-7 adsorbent. The Langmuir model assumes uniform energies of adsorption onto the surface of $\mathrm{NH}_{2}-$ UVM-7. The Langmuir equation is defined as Eq. 2:

$$
\frac{\mathrm{C}_{\mathrm{e}}}{\mathrm{q}_{\mathrm{e}}}=\frac{1}{\mathrm{bQ}_{\max }}+\frac{\mathrm{C}_{\mathrm{e}}}{\mathrm{Q}_{\max }}
$$

Where $C_{e}$ is the equilibrium concentration of metal ions in solution phase $(\mathrm{mg} / \mathrm{L})$ and $q_{e}$ is the amount of metal ions adsorbed at equilibrium $(\mathrm{mg} / \mathrm{g}), Q_{\max }$ is maximum adsorption capacity $(\mathrm{mg} / \mathrm{g})$ on unit mass of adsorbent, and $b$ is the Langmuir constant $(\mathrm{L} / \mathrm{mg})$, related to the free energy of adsorption. The Langmuir model provided a good fit throughout the concentration range. The applicability of the isotherm models and the high values of the correlation coefficients $\left(R^{2}=0.9958\right)$ for $\mathrm{Cr}$ (VI) suggest favourable adsorption by $\mathrm{NH}_{2}$-UVM7 at $45{ }^{\circ} \mathrm{C}$. The value of $Q_{\max }$ in Langmuir plots was $192 \mathrm{mg} / \mathrm{g}$ for $\mathrm{Cr}(\mathrm{VI})$ ions at $45{ }^{\circ} \mathrm{C}$. The values of $Q_{\max }$

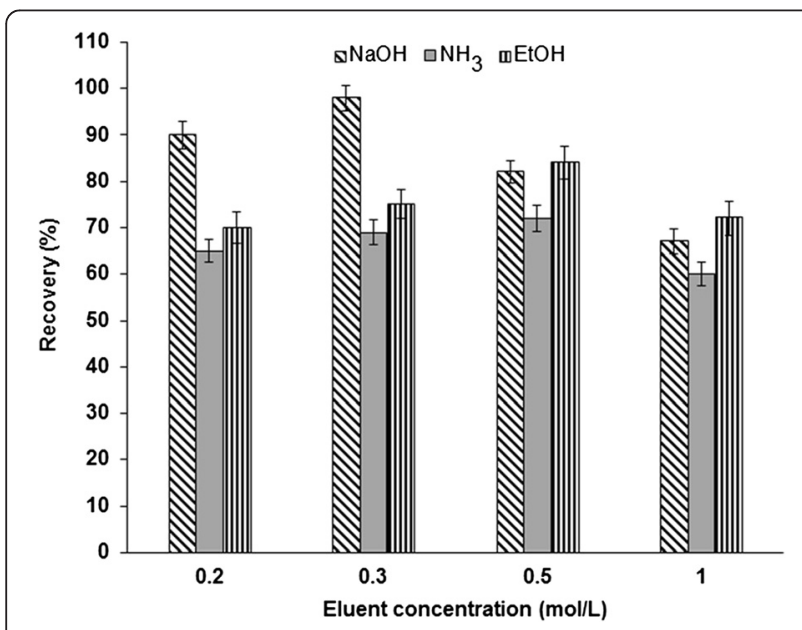

Fig. 8 Effect of different eluents on the recovery of $\mathrm{Cr}(\mathbf{V} \mathbf{l})$ ions from $\mathrm{NH}_{2}-\mathrm{UVM}-7$ phase. Conditions: sample volume $100 \mathrm{~mL}$; solution $\mathrm{pH}$ 2; adsorbent amount $0.12 \mathrm{~g}$; sample flow rate $2.5 \mathrm{~mL} / \mathrm{min}$; eluent volume $1.5 \mathrm{~mL}$ and effective time for flow rate are depended on temperature of solution. According to the results, the maximum capacity of adsorbent in column condition due to the shorter contact time is $5 \%$ less than batch system, which is apparently quite expected. The Langmuir isotherm plots at different temperatures and the value of model constants were shown in Fig. 9 and Table 7, respectively.

\section{Discussion}

The results showed that the quantitative recovery of $\mathrm{Cr}$ (VI) ions was obtained using $12 \mathrm{mg}$ of $\mathrm{NH}_{2}-\mathrm{UVM}-7$ sorbent at $\mathrm{pH}=2$. At sample $\mathrm{pH}$ of $3.5-5, \mathrm{Cr}$ (III) ions physically adsorbed on UVM-7 and $\mathrm{NH}_{2}$-UVM-7 sorbents with recovery percentages of $33 \%$ and $29 \%$, respectively. The $\mathrm{NH}_{2}$ groups functionalized on UVM-7 were used for speciation of chromium ions at optimized $\mathrm{pH}$, but they were decomposed by using strong acid or base. For back extraction of retained $\mathrm{Cr}$ (VI) from $\mathrm{NH}_{2}$ UVM-7, the concentration of sodium hydroxide must be less than $0.5 \mathrm{~mol} / \mathrm{L}$. However, the $\mathrm{pH}$ value of the sample should be adjusted according to the chemistry of the compound of interest. It seems that, at the optimum $\mathrm{pH}$ the $\mathrm{Cr}$ (VI) ions are in the anionic form and so easily complexed with protonated amine groups $\left(\mathrm{NH}_{3}^{+}\right)$of functionalized UVM-7. Therefore, by controlling $\mathrm{pH}$ and amount of sorbent, $\mathrm{Cr}(\mathrm{VI})$ ions can be removed from waters. So, the $\mathrm{NH}_{2}-\mathrm{UVM}-7$ packed micro-column SPE is a favorite method for speciation and determination of chromium ions in environmental samples, and also can be used for on-line removal of $\mathrm{Cr}$ (VI) in water samples at optimum $\mathrm{pH}$ of 2 . Because of high surface area of nanosorbent $(\mathrm{S} / \mathrm{V})$ a very little amount of $\mathrm{NH}_{2}$-UVM-7 $(0.12 \mathrm{~g})$ was used for removal of $\mathrm{Cr}(\mathrm{VI})$ in water sample with good adsorption capacity as $192 \mathrm{mg} / \mathrm{g}$. Understanding the chemistry of the compound with analysis such as ionizability and hydrophobicity can be useful in designing appropriate conditions to obtain efficient extraction recovery. The results of this study showed that the sodium hydroxide solution $(0.3 \mathrm{~mol} / \mathrm{L})$ was more efficient eluent for $\mathrm{Cr}$ (VI) back extraction from the sorbent (Fig. 8). The $\mathrm{NaOH}$ solution is organic free eluent and can prevent co-elution of organic compounds possibly present in the real samples. In the SPE, the volume required to elute the $\mathrm{Cr}(\mathrm{VI})$ from the nanosorbent, depends on the sorbent mass and strength of $\mathrm{Cr}(\mathrm{VI})$ retention by $\mathrm{NH}_{2}-\mathrm{UVM}-7$. In this study, the lowest satisfactory eluent volume is $1.5 \mathrm{~mL}$, giving a suitable preconcentration factor of 66.7. Using this volume, efficient recovery of $97 \%$ can be achieved. In optimized sample volume and sample flow rate less than $5 \mathrm{ml} / \mathrm{min}, \mathrm{Cr}$ (VI) extraction is applicable with an efficient recovery. In this study sample flow rates up to $3 \mathrm{ml} / \mathrm{min}$ were applied with acceptable recovery of $97 \%$. Therefore, to be 
Table 5 The reliability of proposed method for determination and speciation of $\mathrm{Cr}(\mathrm{III})$ and $\mathrm{Cr}(\mathrm{VI})$ in natural water samples

\begin{tabular}{|c|c|c|c|c|c|c|c|}
\hline \multirow[t]{2}{*}{ Sample } & \multicolumn{2}{|c|}{ Added ( $\mu \mathrm{g} / \mathrm{L})$} & \multicolumn{2}{|c|}{ Found $(\mu \mathrm{g} / \mathrm{L})^{\mathrm{a}}$} & \multirow[t]{2}{*}{ Total $\mathrm{Cr}^{\mathrm{a}}$} & \multicolumn{2}{|c|}{ Recovery (\%) } \\
\hline & $\mathrm{Cr}^{3+}$ & $\mathrm{Cr}^{6+}$ & $\mathrm{Cr}^{3+}$ & $\mathrm{Cr}^{6+}$ & & $\mathrm{Cr}^{3+}$ & $\mathrm{Cr}^{6+}$ \\
\hline \multirow[t]{3}{*}{ Tap water } & - & - & $22.8 \pm 1.2$ & $N D^{b}$ & $22.8 \pm 1.2$ & - & - \\
\hline & 50 & - & $71.5 \pm 3.4$ & ND & $71.5 \pm 3.4$ & 97.4 & - \\
\hline & - & 20 & $23.1 \pm 1.8$ & $19.5 \pm 1.1$ & $42.6 \pm 2.3$ & - & 97.5 \\
\hline \multirow[t]{3}{*}{ Drinking water } & - & - & $8.7 \pm 0.4$ & $11.2 \pm 0.5$ & $19.9 \pm 0.7$ & - & - \\
\hline & 50 & - & $57.9 \pm 2.8$ & $10.8 \pm 0.4$ & $68.7 \pm 3.2$ & 98.4 & - \\
\hline & - & 20 & $8.4 \pm 0.3$ & $30.5 \pm 1.3$ & $38.9 \pm 1.6$ & - & 96.5 \\
\hline \multirow[t]{3}{*}{ Waste water ${ }^{c}$} & - & - & $94.6 \pm 4.8$ & $52.3 \pm 3.1$ & $146.9 \pm 6.8$ & - & - \\
\hline & 50 & - & $145.4 \pm 6.5$ & $50.1 \pm 2.7$ & $195.5 \pm 9.6$ & 101.6 & - \\
\hline & - & 50 & $93.3 \pm 4.3$ & $100.6 \pm 5.4$ & $193.9 \pm 8.5$ & - & 96.6 \\
\hline \multirow[t]{3}{*}{ River } & - & - & $17.6 \pm 0.8$ & $9.4 \pm 0.3$ & $27.0 \pm 1.4$ & - & - \\
\hline & 10 & - & $27.3 \pm 1.3$ & $9.6 \pm 0.4$ & $36.9 \pm 1.9$ & 97.0 & - \\
\hline & - & 20 & $17.9 \pm 0.7$ & $28.9 \pm 1.6$ & $46.8 \pm 2.4$ & - & 97.5 \\
\hline \multirow[t]{3}{*}{ Industrial water } & - & - & $49.1 \pm 2.2$ & $125.3 \pm 5.1$ & $174.4 \pm 9.1$ & - & - \\
\hline & 40 & - & $88.6 \pm 4.2$ & $122.7 \pm 4.8$ & $211.3 \pm 9.8$ & 98.8 & - \\
\hline & - & 40 & $48.8 \pm 2.2$ & $163.8 \pm 6.7$ & $212.6 \pm 11.2$ & - & 96.3 \\
\hline
\end{tabular}

${ }^{\mathrm{a}}$ Mean of three determinations \pm confidence interval $(P=0.95, n=5),{ }^{b}$ Not Detected, ${ }^{c}$ from petrochemical factory

confident, the sample flow rate of $2.5 \mathrm{ml} / \mathrm{min}$ was selected, providing a reduced extraction time for as large as $100 \mathrm{~mL}$ sample volume. However, as the results shows, it would be possible to increase the sample flow rate even more as $4 \mathrm{~mL} / \mathrm{min}$ without significant loss in the analyte recovery. In order to show the effect of possible matrix components on the developed method, the interfering effects of various matrix ions, most probably present in the environmental samples were examined (Table 4). The ions added to the samples are mostly present in the real water samples and can be used as closely related interferences present in matrices. The results clearly show the non-effectiveness of the all added components for each concentration on the recoveries obtained from developed method. Many sample preparation methods were used for metal extraction. Recently, liquid-liquid extraction and liquid-liquid microextraction (LLE, LLME) methods have been used for some heavy metals [44]. Although the LLME technique may be useful in some conditions, however the analyte extraction is too hard as such solutions are extremely difficult to be separated. Therefore, due to such problems, nowadays, there is a strong trend towards replacing LLE by SPE. Based on reported methods for

Table 6 Validation of proposed method for chromium determination by certified reference material $(\mathrm{N}=5)$

\begin{tabular}{llll}
\hline Bovine serum & Certified $(\mu \mathrm{g} / \mathrm{L})$ & Found $^{\mathrm{a}}(\mu \mathrm{g} / \mathrm{L})$ & Recovery $(\%)$ \\
\hline NIST SRM 1643e & $20.40 \pm 0.24$ & $19.48 \pm 0.87$ & $95.49 \pm 0.44$
\end{tabular}

${ }^{a}$ Mean value $\pm \mathrm{ts} / \sqrt{ } \mathrm{N}$, SRM 1643 e consists of approximately $250 \mathrm{~mL}$ of acidified water in a polyethylene bottle optimizing of SPE $[45,46]$, authors generally have used 5 factors to optimize the method for environmental samples while, in this study, 8 parameters were screened. This allows that a robust and more reliable method is introduced for environmental monitoring of $\mathrm{Cr}$ (VI) and $\mathrm{Cr}$ (III) ions. Therefore, to make an advantage from this study compare to the other, further experiments of reproducibility of the method were carried out on spiked water samples to validate the possible use of the developed SPE for determination of Cr (VI) and Cr (III) ions. A comparison of the current method with the other reported methods was also given in Tables 8 and 9. It can be seen that the PF and LOD values of the present method, for determination of trace chromium ions, are

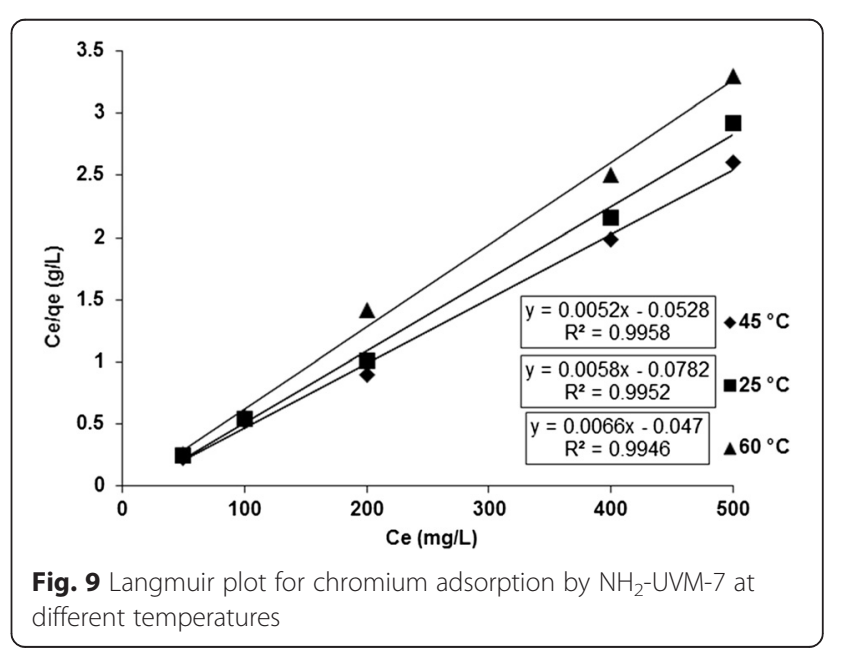


Table 7 The Langmuir isotherm parameters for $\mathrm{Cr}(\mathrm{VI})$ adsorption by $\mathrm{NH}_{2}-\mathrm{UVM}-7$ at different temperatures

\begin{tabular}{lllll}
\hline Temperature $\left({ }^{\circ} \mathrm{C}\right)$ & \multicolumn{2}{l}{ Langmuir isotherm } \\
& $\mathrm{Q}_{\max }(\mathrm{mg} / \mathrm{g})$ & $\operatorname{Max} \mathrm{C}_{\mathrm{e}} / \mathrm{q}_{\mathrm{e}}$ & $\mathrm{R}^{2}$ & $\mathrm{t}_{\text {effective }}(\mathrm{min})$ \\
\hline 25 & 172.4 & 2.61 & 0.9952 & 100 \\
45 & 192.3 & 2.92 & 0.9958 & 88 \\
60 & 151.5 & 3.31 & 0.9946 & 83 \\
\hline
\end{tabular}

better than, or comparable to that reported in the literature [47-56]. The limit of detection, preconcentration factor and adsorption capacity were $1.2 \mu \mathrm{g} / \mathrm{L}, 66.7$, and $192 \mathrm{mg} / \mathrm{g}$, respectively. Lower LOD values of some other works are related with higher sensitivity of the instrument used in these studies (Table 8). Also, the low sample volume $(100 \mathrm{~mL})$ caused to get relatively low preconcentration factor of 66.7. The adsorption of chromium ions on the most adsorbent used in SPE techniques requires formation of hydrophobic complexes using chelating agents [52-54]. However, in the developed method, $\mathrm{NH}_{2}-\mathrm{UVM}-7$ was investigated as a novel sorbent for the speciation and preconcentration of trace amounts of $\mathrm{Cr}$ (VI) and $\mathrm{Cr}$ (III) ions without application of any chelating agents. Hazer and Demir used SPE method based on Poly 1, 3-thiazol-2-yl methacrylamideco-4-vinyl pyridine-co-divinylbenzene for the speciation analysis of chromium. The limit of detection, preconcentration factor and adsorption capacity were obtained as $2.4 \mu \mathrm{g} / \mathrm{L}, 30$ and $80 \mathrm{mg} / \mathrm{g}$, respectively [56]. Duran et al. used activated carbon from tea-industry wastes (TIWAC) for preconcentration and speciation of chromium without complexing agent, prior to determination by flame atomic absorption spectrometry [55]. The preconcentration factor and adsorption capacity for activated carbon were 50 and $61 \mathrm{mg} / \mathrm{g}$, respectively. Soylak et al. studied on chromium speciation based on coprecipitation of Cr (III) by using praseodymium (III) hydroxide $\left(\mathrm{Pr}(\mathrm{OH})_{3}\right)$ precipitate and neodymium (III) Hydroxide. In their studies, the recovery extraction for

Table 8 Comparison of the proposed SPE/F-AAS method with various reported procedures for determination of chromium in water samples

\begin{tabular}{lllll}
\hline Detection method & Separation technique & $\mathrm{PF}^{\mathrm{a}}$ & $\mathrm{LOD}^{\mathrm{b}}(\mu \mathrm{g} / \mathrm{L})$ & Reference \\
\hline ICP -MS & DLLME $^{\mathrm{C}}$ & - & 0.110 & {$[48]$} \\
ET-AAS & SPE $^{\mathrm{d}}$ & 20 & 0.050 & {$[49]$} \\
ET-AAS & BDES $^{\mathrm{e}}$ & 27 & 0.010 & {$[50]$} \\
F-AAS & CPE $^{\mathrm{f}}$ & 58 & 0.180 & {$[51]$} \\
CAdSV $^{\mathrm{a}}$ & EDCS $^{\mathrm{g}}$ & - & 0.007 & {$[47]$} \\
F-AAS & SPE $^{\mathrm{h}}$ & 66.7 & 1.2 & This work
\end{tabular}

${ }^{\mathrm{a}}$ Preconcentration factor, ${ }^{\mathrm{b}}$ Limit of detection, ${ }^{\mathrm{c}}$ Dispersive liquid- liquid micro extraction, ${ }^{d}$ Solid phase extraction, ${ }^{\mathrm{e}} \mathrm{Bi}$-directional electrostacking, ${ }^{\mathrm{f}} \mathrm{Cloud}$ point extraction, ${ }^{\mathrm{g}}$ Electro deposition on cell surface, ${ }^{\mathrm{h}}$ Nano solid phase extraction by $\mathrm{NH}_{2}-\mathrm{UVM}-7$
Cr (VI), LOD and PF was lower than our developed method $[57,58]$. Finally, the developed method based on the combination of $\mathrm{NH}_{2}$-UVM-7 packed micro-column SPE and F-AAS detection method was successfully applied for speciation and determination of $\mathrm{Cr}$ (III)/Cr (VI) ions in real water samples. In addition, the $\mathrm{NH}_{2}$ UVM-7 can be used for removal of $\mathrm{Cr}$ (VI) in water samples with high capacity and good repeatability.

\section{Conclusions}

The simple, fast, reliable, and economical technique for speciation and determination of trace amount of $\mathrm{Cr}(\mathrm{VI})$ and $\mathrm{Cr}$ (III) ions in real water samples was developed by combining the SPE technique based on $\mathrm{NH}_{2}-\mathrm{UVM}-7$ adsorbent with F-AAS detection method. The developed method allows us to obtain good recovery $(>97 \%)$, reproducibility, and good preconcentration factor (66.7) without using the chelating agent. In addition, the method was free of interference. Factors influencing the SPE method were optimized. The recovery efficiency of UVM-7 and $\mathrm{NH}_{2}$-UVM-7 for Cr (VI) were found to be $5 \%$ and $96 \%$, respectively, at $\mathrm{pH}=2$. So, the extraction recoveries of $\mathrm{Cr}(\mathrm{VI})$ anion are depended on chemically adsorption by protonated amine group $\left(\mathrm{NH}_{3}^{+}\right)$of $\mathrm{NH}_{2}-$ UVM-7. The developed SPE/F-AAS method based on $\mathrm{NH}_{2}$-UVM-7 sorbent was successfully applied for speciation and determination of $\mathrm{Cr}$ (VI) and $\mathrm{Cr}$ (III) ions in real water samples. This method is comparable respect to powerful techniques as DLLME-ET-AAS (Table 8). The adsorption capacity of $\mathrm{NH}_{2}-\mathrm{UVM}-7$ for $\mathrm{Cr}$ (VI) ions is higher than that chelate modified SPE procedures reported in literature up to now (Table 9). The developed procedure has some advantages over other SPE methods in literature, such as low consumption of only $0.12 \mathrm{~g}$ $\mathrm{NH}_{2}$-UVM-7 as adsorbent and also $1.5 \mathrm{~mL}$ of eluent per extraction, high sorption capacities, low detection limits, good preconcentration factor and good reusability (up to 15 cycles). The developed method can be used for removal of $\mathrm{Cr}(\mathrm{VI})$ in water samples at optimized pH. It is

Table 9 Comparison of the proposed method with other SPE procedures for determination of chromium in water samples

\begin{tabular}{lllll}
\hline SPE adsorbent & LOD $^{\mathrm{a}}(\mu \mathrm{g} / \mathrm{L})$ & PF $^{\mathrm{b}}$ & $\begin{array}{l}\text { Adsorption } \\
\text { capacity }(\mathrm{mg} / \mathrm{g})\end{array}$ & Reference \\
\hline DPC-Poly C-18 $^{\mathrm{c}}$ & 2.4 & 12 & $-\ldots-\ldots$ & {$[52]$} \\
ENVI-18 DSK $^{\text {TM }}$ disk & 20 & 300 & $-\ldots-$ & {$[53]$} \\
APDC/MWCNT $^{\mathrm{d}}$ & 0.96 & 100 & 9.5 & {$[54]$} \\
TIWAC $^{\mathrm{C}}$ & 4.5 & 50 & 61.0 & {$[55]$} \\
Polymer $^{\mathrm{f}}$ & 2.4 & 30 & 80.2 & {$[56]$} \\
NH $_{2}$-UVM-7 & 1.2 & 66.7 & 192.0 & This work
\end{tabular}

a Limit of detection, ${ }^{b}$ Pre-concentration factor, ${ }^{c} 1,5$-diphenylcarbohydrazide (DPC)-Polysorb C-18 beads, 'Ammonium pyrrolidine dithiocarbamate (APDC)/ multi-walled carbon nanotubes, ${ }^{\mathrm{e}} \mathrm{Tea}$-industry waste activated carbon, ${ }^{\mathrm{f}} \mathrm{Poly}$ (1,3-thiazol-2-yl methacrylamide-co-4-vinyl pyridine-co-divinylbenzene) 
expected that the developed method could successfully be utilized for speciation, preconcentration, and determination of chromium ions in different environmental and biological samples.

\section{Competing interests}

The authors declare that they have no competing interests.

\section{Authors' contributions}

$\mathrm{HSH}, \mathrm{ZS}$ and $\mathrm{AKH}$ participated in the design of the study, analysis, interpretation of data and helped to draft the manuscript. FG supervised the study in all steps and has been consulted by AV. Technical assistance has been provided by AMR. All authors read and approved the final manuscript.

\section{Acknowledgements}

The authors are thankful to the Iranian Petroleum Industry Health Research Institute (IPIHRI) and Research Institute of Petroleum Industry (RIPI), Tehran, Iran, for their support for this work. The authors are thankful to M.J. Kian and F. Eftekhar, S. H. Abbasi and A. M. Mortazavi for supporting this work.

\section{Author details}

'Occupational and Environmental Health Research Center (OEHRC), Iranian Petroleum Industry Health Research Institute (IPIHRI-PIHO), Tehran 1485733111, Iran. ${ }^{2}$ Research Institute of Petroleum Industry (RIPI), Tehran 14665-1137, Iran. ${ }^{3}$ Department of Chemistry, Semnan University, Semnan 35131-1911, Iran. ${ }^{4}$ Occupational Health Engineering Department, School of Public Health, Tehran University of Medical Sciences, Tehran 6446-14155, Iran.

Received: 25 March 2014 Accepted: 12 May 2015

Published online: 22 May 2015

\section{References}

1. Okoronkwo NE, Igwe GC, Onwuchekwa EC. Risk and health implications of polluted soils for crop production. African J Biotechnol. 2005;4:1521-4.

2. Dhankhar R, Chhikara S, Rana L, Sangwan S. Impact assessment of soils treated with refinery effluent. Eur J Soil Biol. 2009;45:459-65.

3. Atubi $\mathrm{O}$. Effects of warri refinery effluents on water quality from the Iffie River, Delta State, Nigeria. American Rev Polit Econ. 2011;9:45-56.

4. Asgharipour MR, Sirousmehr AR. Comparison of three techniques for estimating phytotoxicity in municipal solid waste compost. Ann Biol Res. 2012;3:1094-101

5. Duruibe JO, Ogwuegbu MOC, Egwurugwu JN. Toxicity, heavy metal pollution and human biotoxic effects. Int J Phy Sci. 2007;2:112-8.

6. U.S. Department of Health and Human Services: Chromium. National Institute for Occupational Safety and Health (NIOSH). Atlanta, GA: Centers for Disease Control (CDC), publication No: CDC-2005-149; 2007.

7. U.S. Department of Occupational Safety and Health. Toxic and hazardous substances. Atlanta, GA: Occupational safety and health standards, Occupational Safety and Health Administration (OSHA), Code of Federal Regulations: 29 CFR 1910.100; 2012.

8. U.S. Office of Water \& Waste Management. Drinking water standards and health advisories. Washington, DC: Environmental Protection Agency (EPA) EPA Code: 820-R-11-002; 2011.

9. Katz SA, Salem S. The toxicity of chromium with respect to its chemical speciation: a review. J Appl Toxicol. 2006;13:217-24.

10. Kotas J, Stasicka Z. Chromium occurrence in the environment and methods of its speciation. Environ Pollut. 2000;107:263-83.

11. U.S. Department of Health and Human Services: toxicological profile for chromium. Public Health Service, Agency for Toxic Substances and Disease Registry (ATSDR), Publication No: ATSDR-HE-CS-2001-0005; 2000.

12. U.S. Department of Human Hazardous Exposure. Documentation of the Threshold Limit Values and Biological Exposure. Index 7th Ed. Atlanta, GA: American Conference of Governmental Industrial Hygienists (ACGIH); 2011.

13. National Health and Nutrition Examination Survey (NHNES). Chromium compounds. Atlanta, GA, USA: Centers for Disease Control; 2010.

14. International Program on Chemical Safety (IPCS): Chromium. Environmental Health Criteria 61. Switzerland: World Health Organization; 2003 [http://www.inchem.org/documents/ehc/ehc/ ehc61.htm]
15. Laborda F, Grriz M, Bolea E, Castillo J. Determination of total and soluble Cr (VI) in compost by ion chromatography-inductively coupled plasma mass spectrometry. Int J Environ An Ch. 2007:87:227-35.

16. Hosseini MS, Belador F. $\mathrm{Cr}(\mathrm{III}) / \mathrm{Cr}(\mathrm{VI})$ speciation determination of chromium in water samples by luminescence quenching of quercetin. J Hazard Mater. 2009;165:1062-7.

17. Jorge EO, Rocha MM, Fonseca ITE, Neto MMM. Studies on the stripping voltammetric determination and speciation of chromium at a rotating-disc bismuth film electrode. Talanta. 2010;81:556-64.

18. Kiran K, Kumar KS, Prasad B, Suvardhan K, Babu LR, Janardhanam K. Speciation determination of $\mathrm{Cr}(\mathrm{III})$ and $\mathrm{Cr}(\mathrm{VI})$ using preconcentration cloud point extraction with flame atomic absorption spectrometry. J Hazard Mater. 2008;150:582-6.

19. Chai ZF, Zhang ZY, Feng WY, Chen CY, Xu DD, Hou XL. Study of chemical speciation of trace elements by molecular activation analysis and other nuclear techniques. J Anal At Spectrom. 2004;19:26-33.

20. Suleiman JS, Hu B, Huang CZ. On-line speciation of $\mathrm{Cr}$ (III) and $\mathrm{Cr}(\mathrm{VI})$ using microcolumn packed with immobilized used green tea leaves (UGTLs) and determination by ICP-OES in environmental water samples. Atom Spec. 2007;28:234-40.

21. Rahman GMM, Kingston HMS, Towns TG, Vitale RJ, Clay KR. Determination of hexavalent chromium by using speciated isotope-dilution mass spectrometry after microwave speciated extraction of environmental and other solid materials. Anal Bioanal Chem. 2005;382:1111-20.

22. Burguera M, Burguera JL. On-line electrothermal atomic absorption spectrometry configurations, Atomic Spectroscopy. Spectrochim Acta B. 2007:62:884-96.

23. Olmedo P, Pla A, Hernandez AF, Lopez-Guarnido O, Rodrigo L, Gil F. Validation of a method to quantify chromium, cadmium, manganese, nickel and lead in human whole blood, urine, saliva and hair samples by electrothermal atomic absorption spectrometry. Anal Chim Acta. 2010;659:60-7.

24. Beni A, Karosi R, Posta J. Speciation of hexavalent chromium in waters by liquid-liquid extraction and GFAAS determination. Microchem J. 2007:85:103-8.

25. Shirkhanloo H, Khaligh A, Mousavi HZ, Eskandari MM, Miran-Beigi AA. Ultra-trace speciation and determination in blood samples by ionic liquid-based dispersive liquid-liquid microextraction. Chem papers. 2015;69:779-90.

26. Ebrahimzadeh $\mathrm{H}$, Yamini $Y$, Kamare F, Shariati S. Homogeneous liquid-liquid extraction of trace amounts of mononitrotoluenes from waste water samples. Anal Chim Acta. 2007;594:93-100.

27. Li Z, Chang X, Hu Z, Huang X, Zou X, Wu Q, et al. Zincon-modified activated carbon for solid-phase extraction and preconcentration of trace lead and chromium from environmental samples. J Hazard Mater. 2009;166:133-7.

28. Narin I, Kars A, Soylak M. Novel solid phase extraction procedure on amberlite XAD-1180 for speciation of $\mathrm{Cr}$ (III), $\mathrm{Cr}(\mathrm{VI})$ and total chromium in environmental and pharmaceutical samples. J Hazard Mater. 2008;150:453-8.

29. Zeng C, Lin Y, Zhou N, Zheng J, Zhang W. Room temperature ionic liquids enhanced the speciation of $\mathrm{Cr}(\mathrm{VI})$ and $\mathrm{Cr}$ (III) by hollow fiber liquid phase microextraction combined with flame atomic absorption spectrometry. J Hazard Mater. 2012;237:365-70.

30. Liang $P$, Sang $H$. Speciation of chromium in water samples with cloud point extraction separation and preconcentration and determination by graphite furnace atomic absorption spectrometry. J Hazard Mater. 2008;154:1115-9.

31. Soliman EM, Saleh MB, Ahmed S. Alumina modified by dimethyl sulfoxide as a new selective solid phase extractor. Talanta. 2006;69:55-60.

32. Thielemann J, Girgsdies F, Schlogl R, Hess C. Pore structure and surface area of silica SBA-15, influence of washing and scale up. Beilstein J Nanotechnol. 2011:2:110-8.

33. Kokunešoski M, Gulicovski J, Matovic B, Logar M, Milonjic SK, Babic B. Synthesis and surface characterization of ordered mesoporous silica SBA-15. Mater Chem Phys. 2010;124:1248-52.

34. Lenin H, Carmen G, Julio L, Aurelio B, Ramon MM, Dolores M, et al. Bases for the synthesis of nanoparticulated silicas with bimodal hierarchical porosity. Solid State Sci. 2006:8:940-51.

35. Taguchi A, Schuth F. Ordered mesoporous materials in catalysis. Microp Mesop Mater. 2005;77:1-45.

36. Nakanishi K, Tanaka N. Sol-gel with phase separation, hierarchically porous materials optimized for high-performance liquid chromatography separations. Acc Chem Res. 2007;40:863-73. 
37. Zanjanchi MA, Ebrahimian A, Alimohammadi Z. A spectroscopic study on the adsorption of cationic dyes into mesoporous AIMCM-41 materials. Optical Mater. 2007;29:794-800.

38. Lu J, Liong M, Zink JI, Tamanoi F. Mesoporous silica nanoparticles as a delivery system for hydrophobic anticancer drugs. Small. 2007;8:1341-6.

39. Slowing II, Trewyn BG, Lin VSY. Mesoporous silica nanoparticles for intracellular delivery of membrane-impermeable proteins. J Am Chem Soc. 2007;129:8845-9

40. Torney F, Trewyn BG, Lin VSY. Mesoporous silica nanoparticles deliver DNA and chemicals into plants. Nature Nanotech. 2007;2:295-300.

41. Yang $H, X u R$, Xue XM, Li FT, Li GT. Hybrid surfactant template mesoporous silica formed in ethanol and its application for heavy metal removal. J Hazard Mater. 2008;152:690-8.

42. Xue XM, Li FT. Removal of Cu (II) from aqueous solution by adsorption onto functionalized SBA-16 mesoporous silica. Microporous Mesoporous Mater. 2008;116:116-22.

43. El Haskouri J, Morales JM, Ortizde Zárate D, Fernández L, Latorre J, Guillem C, et al. Nanoparticulated silicas with bimodal porosity: chemical control of the pore sizes. Inorg Chem. 2008;47:8267-77.

44. Bouabdallah I, Zidane I. Liquid-liquid extraction of copper (II), cadmium (II), and lead (II) using tripodal N-donor pyrazole ligands. Arkivok. 2006;11:59-65.

45. Tuzen M, Narin I. Solid phase extraction system for atomic absorption spectrometric determination of some trace metals in environmental samples (XAD-4/PAN). Anal Lett. 2004;37:473-89.

46. Soylak M, Dogan M. Column preconcentration/separation and atomic absorption spectrometric determinations of some heavy metals in table salt samples using amberlite XAD-1180. Turk J Chem. 2003;27:235-42.

47. Bobrowski A, Mocak J, Dominik J, Pereira H, Knap W. Metrological characteristics and comparison of analytical methods for determination of chromium trace in water samples. Acta Chim Slov. 2004;51:77-93.

48. Ina R, Audrius $\mathrm{P}$, Birut $\mathrm{P}$, Evaldas N. Determination of $\mathrm{Cr}(\mathrm{VI})$ by dispersive liquid-liquid microextraction and dried-droplet laser ablation ICP-MS. Cur Anal Chem. 2010;6:310-5.

49. Xue A, Qian S, Huang G, Chen L. Separation and preconcentration of chromium speciation on chitosan and determination by graphite furnace atomic absorption spectrometry. J Anal At Spectrom. 2000;15:1513-5.

50. Yang L, He Y, Gan W, Li M, Qu Q, Lin X. Determination of Cr (VI) and Pb (II) in drinking water by electrokinetic flow analysis system and graphite furnace atomic absorption spectrometry. Talanta. 2001;55:271-9.

51. Agrawal YK, Sharma KR. Speciation, liquid-liquid extraction, sequential separation, preconcentration, transport and ICP-AES determination of $\mathrm{Cr}$ (III), Mo (VI) and W (VI) with calix-crown hydroxamic acid in high purity grade materials and environmental samples. Talanta. 2005;67:112-20.

52. Wang J, Xue B. Sequential injection analysis for $\mathrm{Cr}(\mathrm{VI})$ and $\mathrm{Cr}$ (III) with renewable surface reflection spectrophotometry. Anal Sci. 2006;22:1233-6.

53. Mohammadhosseini M, Tehrani MS, Ganjali MR. Preconcentration, determination and dpeciation of chromium(III) using solid phase extraction and flame atomic absorption spectrometry. J Chin Chem Soc. 2006;53:549-57.

54. Tuzen M, Soylak M. Multiwalled carbon nanotubes for speciation of chromium in environmental samples. J Hazard Mater. 2007;147:219-22.

55. Duran C, Ozdes D, Gundogdu A, Imamoglu M, Senturk HB. Tea-industry waste activated carbon, as a novel adsorbent, for separation, preconcentration and speciation of chromium. Anal Chim Acta. 2011;688:75-83.

56. Hazer O, Demir D. Speciation of chromium in water samples by solid-phase extraction on a new synthesized adsorbent. Anal Sci. 2013;29:729-34.

57. Soylak M, Aydin A. Speciation of $\mathrm{Cr}$ (III) and $\mathrm{Cr}(\mathrm{VI})$ in environmental samples by using coprecipitation with praseodymium(III) hydroxide and determination by flame atomic absorption spectrometry. J Iranian Chem Soc. 2012;9:263-7.

58. Soylak M, Kizil N. Neodymium (III) hydroxide coprecipitation-FAAS system for the speciation of chromium in natural waters. Atom Spect. 2013;34:216-20.

\section{Submit your next manuscript to BioMed Central and take full advantage of:}

- Convenient online submission

- Thorough peer review

- No space constraints or color figure charges

- Immediate publication on acceptance

- Inclusion in PubMed, CAS, Scopus and Google Scholar

- Research which is freely available for redistribution 